Volume 9, Issue 1, 203 - 213.

ISSN: 2165-8714

http://www.eu-jer.com/

\title{
Emotional Intelligence of Elementary Scholar: Instructional Strategy and Personality Tendency
}

\author{
Nilawati Tadjuddin* \\ Universitas Islam Negeri Raden \\ Intan Lampung, INDONESIA
}

Rifda El-Fiah

Universitas Islam Negeri Raden Intan

Lampung, INDONESIA

\author{
Robingatin \\ Institut Agama Islam Negeri \\ Samarinda, INDONESIA
}

\author{
Meriyati \\ Universitas Islam Negeri Raden \\ Intan Lampung, INDONESIA
}

\author{
Eti Hadiati \\ Universitas Islam Negeri Raden \\ Intan Lampung, INDONESIA
}

\author{
Ahmad Walid \\ Institut Agama Islam Negeri Bengkulu, \\ INDONESIA
}

\author{
Widayanti \\ Sekolah Tinggi Keguruan dan Ilmu \\ Pendidikan Nurul Huda, INDONESIA
}

Received: December 10, 2019 - Revised: December 27, 2019 - Accepted: January 15, 2019

\begin{abstract}
Each child has a different personality type of tendency. Personality type is closely related to emotional intelligence. Through this study, we report the analysis results of the effects of personality type tendencies and the application of learning strategies in controlling the emotional intelligence of elementary school students. This study uses the quasi-experimental method with a $2 \times 2$ factorial design in data collection. Data analysis used was a two-way analysis of variance (ANOVA) test. Research findings show that students with extrovert tendencies personality are better than students with introvert personality types. The application of inquiry strategies in learning is better at controlling emotional intelligence than the application of expository strategies.
\end{abstract}

Keywords: Students' emotional intelligence, elementary school students' learning strategies, students' personality types.

To cite this article: Tadjuddin, N., Robingatin, Meriyati, Hadiati, E., El-Fiah, R., Walid, A., \& Widayanti (2020). Emotional intelligence of elementary scholar: instructional strategy and personality tendency. European Journal of Educational Research, 9(1), 203-213. https://doi.org/10.12973/eu-jer.9.1.203

\section{Introduction}

God created humans as intelligent beings (Felix, Marpaung, \& Akmal, 2019; Sahputra \& Hayati, 2019). The level of intelligence of a person depends on a particular place and culture, thus, producing different ways of thinking and individual intelligence (Mamangkey, Tewal, \& Trang, 2018; Suryana, 2019). Multiple intelligence was chosen as a concept in seeing descriptively how individuals use their intelligence to solve problems (Mujib \& Mardiyah, 2017; Oktaviana, Jufrida, \& Darmaji, 2016). One indicator of multiple intelligences is emotional intelligence (Asmawati, 2017). The emotional intelligence is a self-domain (self-awareness), self-control (self-regulation), motivation (self-motivation), empathy (self-empathy), and social skills (Goleman, 2001).

Emotional intelligence in the scope of education is important for elementary school students (Asmawati, 2017; Baharuddin \& Dalle, 2019; Valoka, Tsausi, \& Nikolaou, 2004). Achievement, behavior, social, self-concept, and personality of students affect emotional intelligence (Haryadi \& Aripin, 2015; Indriawati, 2018). Emotional intelligence is very important to be taught and applied in the family and educational environment (Asmawati, 2017; Sahputra \& Hayati, 2019; Sinetar, 2000). Based on research from the United States and Europe, the emotional intelligence of elementary school students can be controlled through learning by playing (Baidi, 2019). However, Asian countries still choose academic learning over games, even, in Asian countries, the parents still assume that playing is not learning (Hedges \& Lee, 2010; Parmar, Harkness, \& Super, 2004). Bearing in mind the many impacts that the elementary school students could have from learning by playing, there is a need for socialization from teachers to parents of elementary school students (Soemarmi, 2017; Zaini, 2015).

Various positive impacts obtained from learning by playing include feeling happy, interested, creative, even having a direct experience that can be applied in the environment of daily-life (Indrawati, 2013; Parmin et al, 2019; Soemarmi, 2017; Yuberti et al., 2019). Besides, learning by playing can show the personality types of students (Rasyid, Apriani,

\footnotetext{
* Corresponding author:

Nilawati Tadjuddin, Universitas Islam Negeri Raden Intan, Lampung, Indonesia. $\bowtie$ nilawati@radenintan.ac.id
} 
Irianti, \& Verlanda, 2017). Learning by playing a game requires special strategies to work well (Felix et al., 2019; Rachmawati \& Kurniati, 2011; Saregar et al, 2019). The various strategies that can be applied include inquiry learning and expository strategies (Abdurrahman, 2017; Dewi, 2016; Nasution, 2018; Wangsa-P., Suyana, Amalia, \& Setiawan, 2017; Soemarmi, 2017). Student-centered inquiry learning strategies and teacher-centered expository learning are expected to make it easier to analyze students' emotional intelligence (Choerunnisa, Wardani, \& Sumarti, 2017; Dewi, Suyatna, \& Ertikanto, 2017; Purnamawati, Ertikanto, \& Suyatna, 2017).

However, research related to emotional intelligence has been rarely done, especially its impact in the field of education. The exercise of emotional intelligence will have an impact on the formation of more realistic thinking in supporting the future (Hanana, 2018). Specifically in overcoming the limitations of natural resources and preservation efforts in Indonesia (Komarudin, Alkhudri, Ubedilah, Syaifudin, \& Casmana, 2019). Indonesia has sufficient available energy sources but has not been fully utilized including in its preservation (Asmuniv, 2015; D. Hidayati, 2016; Warjiyono, 2016; Widayanti, Abdurrahman, \& Suyatna, 2019). So it is necessary to get used to controlling emotional intelligence through cases in Indonesia.

Several previous studies have examined emotional intelligence including: analyzing the relationship of emotional intelligence and employee performance (Brunetto, Teo, Shacklock, \& Farr-wharton, 2012; Cartwright \& Pappas, 2008; Farrastama \& Asmony, 2019; Feyerhem \& Rice, 2002; Harahap \& Sagala, 2019; Ibrahim, 2012; O'Boyle Jr, Humphrey, Pollack, Hawver, \& Story, 2011; Kirk, Schutte, \& Hine, 2011; Krisnanda, Bagus, \& Surya, 2019; Mamangkey et al., 2018; Mulyasari, 2018), the nature of emotional intelligence in adolescents (Argyriou, Bakoyannis, \& Tantaros, 2016), the effect of emotional intelligence on work practices (Athariq \& Andayono, 2019), the effect of emotional intelligence on pro-social behavior (Hanana, 2018; Sahputra \& Hayati, 2019), portrait of emotional intelligence in students (Birks, Mckendree, \& Watt, 2009; Indriawati, 2018; Luan \& Blegur, 2018), the role of emotional intelligence in coping strategies (Felix et al., 2019), the importance of emotional intelligence for leadership (Allameh \& Khazaei, 2015; Suryana, 2019), description of emotional intelligence in gifted students (Respati, Arifin, \& Ernawati, 2007), consumer emotional intelligence (Kidwell, Hardesty, \& Childers, 2008), and the importance of emotional intelligence in learning. From the most recent research, most of the emotional intelligence research applied to the working-age, only a few that examines emotional intelligence in the educational environment. In this study, emotional intelligence is applied in the educational environment through learning strategies and personality types. Also, the application is carried out on elementary school students.

\section{Method}

\section{Research Design}

This research uses a quasi-experimental method with a 2x2 factorial design (Ferreira, Morais, Brothers, \& Ferreira, 2019; Sakib, Muhammad, \& Osman, 2019). The variables in this study are learning strategies and personality types as independent variables, while emotional intelligence is the dependent variable. The design of this study pays attention to the possibility of a moderate variable affecting treatment (the independent variable) on the outcome (the dependent variable) (Keeler, Skidmore, Leenstra, Macdonald, \& Stewart, 2019). The factorial design in this study is shown in table 1 (Yang, Wang, \& Chiu, 2015).

Tabel 1. Factorial Design

\begin{tabular}{cccc}
\hline Learning Strategies & $\begin{array}{c}\text { Expository } \\
\left(\mathbf{A}_{\mathbf{1}}\right)\end{array}$ & $\begin{array}{c}\text { Inquiry } \\
\left(\mathbf{A}_{\mathbf{2}}\right)\end{array}$ & Number \\
\hline Personality Types & $\mathrm{A}_{1} \mathrm{~B}_{1}$ & $\mathrm{~A}_{2} \mathrm{~B}_{1}$ & 30 \\
\hline Extrovert $\left(\mathbf{B}_{\mathbf{1}}\right)$ & $\mathrm{A}_{1} \mathrm{~B}_{2}$ & $\mathrm{~A}_{2} \mathrm{~B}_{2}$ & 30 \\
Introvert $\left(\mathbf{B}_{2}\right)$ & 30 & 30 & 60 \\
\hline Total & & &
\end{tabular}

\section{Sample and Data Collection}

The study population was 60 first grade students of Pahoman Elementary School, Bandar Lampung. The sampling technique was done in stages (random sampling). Before the treatments were given, the students were given a personality type test by a psychologist to determine the tendency for extrovert or introvert personality types. Then, $50 \%$ of the students were categorized to have extrovert tendencies and $50 \%$ of the students were categorized to have introvert tendencies.

The instrument used in this study was a questionnaire. The questionnaire used was a close-ended questionnaire with several choices that had been provided by researchers related to the emotional intelligence indicators. The data was then analyzed using interpretations in the form of assessment scores. The scores' values ranged from 1 to 4 . The highest score is 4 and the lowest score is 1 for each questionnaire item selected. 


\section{Analyzing the Data}

The data were analyzed quantitatively using a two-way analysis of variance (ANOVA) (Rita, 2019; Sudrajat, Iasha, \& Femayati, 2018). Before the ANOVA test was performed, the prerequisite tests of normality and homogeneity tests were conducted. The instrument validation test was performed using the Pearson Product Moment correlation technique formula with the Alpha Coefficient of Cronbach to calculate the reliability of the instrument.

\section{Findings}

This study applies expository and inquiry strategies in learning both for students who have extrovert and introvert tendencies. The research design carried out in the application of expository and inquiry strategies on extrovert and introvert personality types is shown in Figure 1,
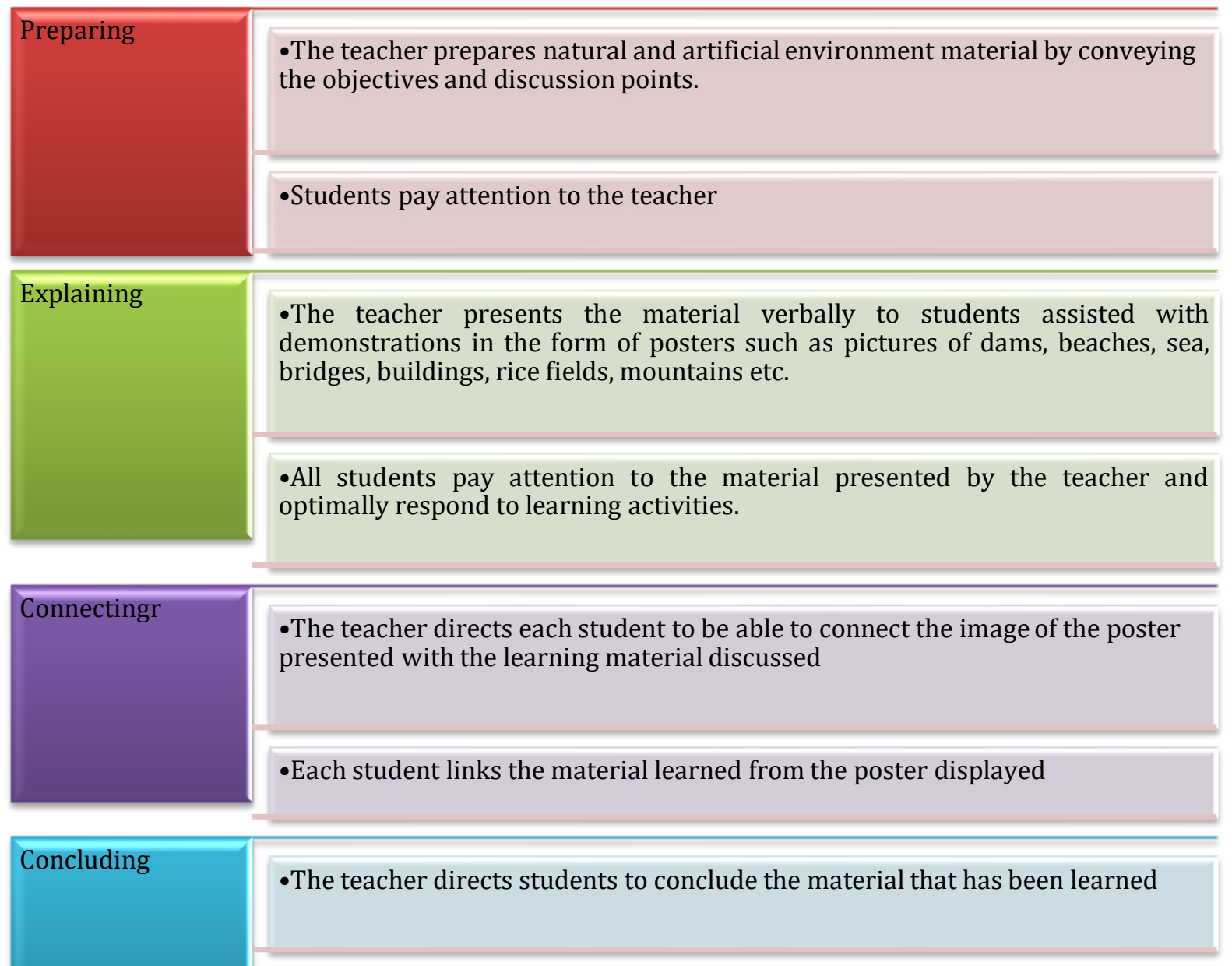

-Each student concludes the learning that has been done

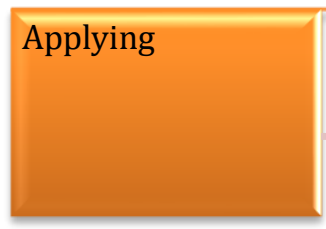

-The teacher directs students to be able to apply a caring attitude to the environment by protecting the natural environment

-All students learn to apply energy saving in everyday life

Figure 1. Expository Strategy Implementation Design in Measuring Students' emotional Intelligence 


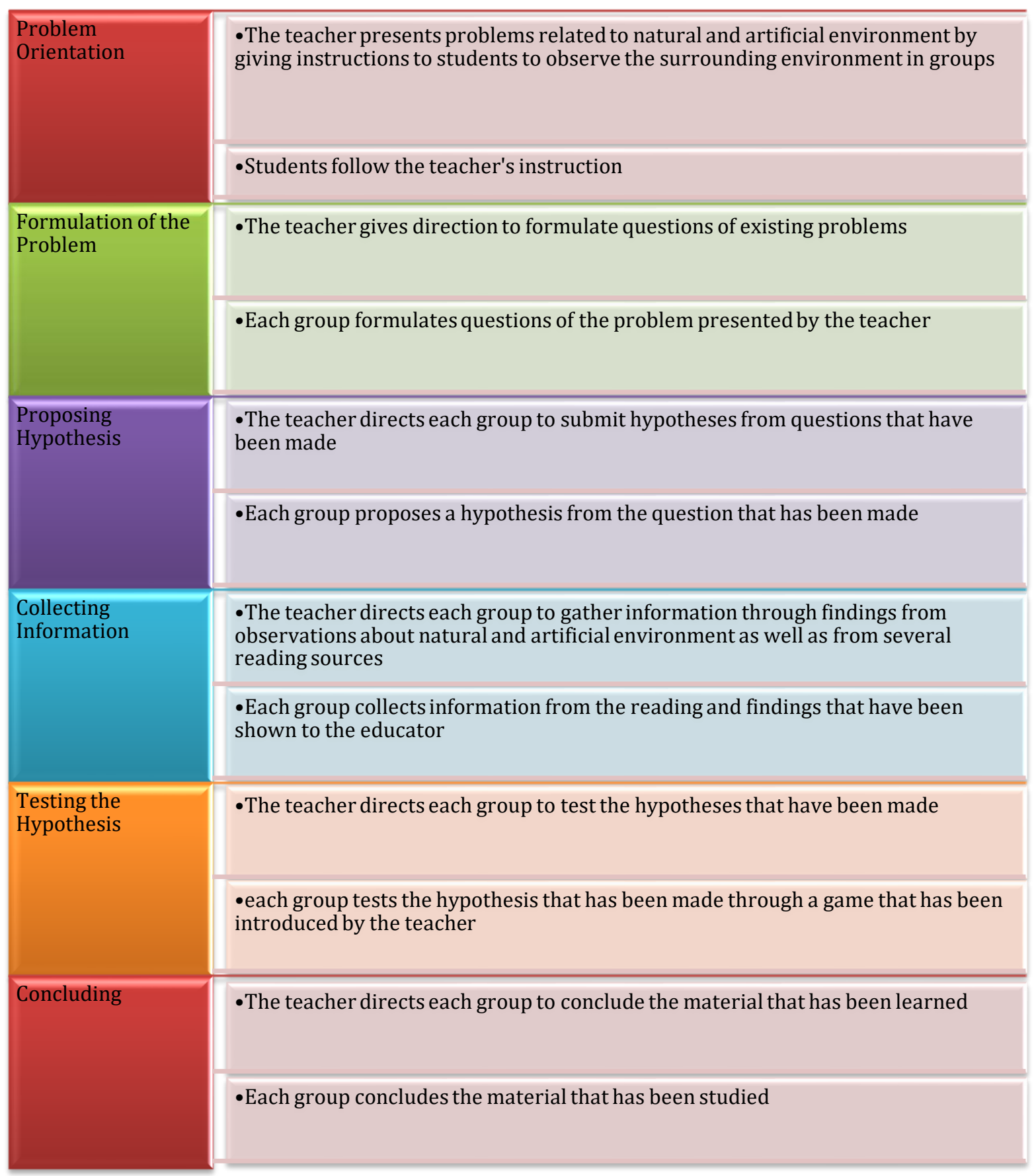

Figure 2. Inquiry Strategy Application Design in Measuring Students' Emotional Intelligence

The same treatment between extrovert and introvert personality types (see figures 1 and 2) was given to both personality types in the form of expository and inquiry learning strategies to measure emotional intelligence. The results of the were analyzed using the two-way ANOVA test, before conducting the test, the normality and homogeneity tests were first performed to determine the emotional intelligence based on personality types and learning strategies. The following data is the result of the research.

Table 2. The Normality Test Results for the Students' Emotional Intelligence

\begin{tabular}{ccccc}
\hline Data & $\mathbf{N}$ & $\mathbf{L}_{\mathbf{h}}$ & $\mathbf{L}_{\mathbf{t}(\boldsymbol{\alpha}=\mathbf{0 . 0 5})}$ & Result \\
\hline A1 & 30 & 0.112329 & 0.2200 & Normal \\
A2 & 30 & 0.66610 & 0.2200 & Normal \\
B1 & 30 & 0.123777 & 0.2200 & Normal \\
B2 & 30 & 0.128259 & 0.2200 & Normal \\
A1 B1 & 15 & 01301195 & 0.2200 & Normal \\
A2 B2 & 15 & 0.144969 & 0.2200 & Normal \\
A1 B2 & 15 & 0.076183 & 0.2200 & Normal \\
A2 B2 & 15 & 0.185243 & 0.2200 & Normal \\
\hline
\end{tabular}


Table 3. Variance Homogeneity Test of Emotional Intelligence in the Two Treatment Groups and Two Category Attributes

\begin{tabular}{|c|c|c|c|c|c|c|}
\hline \multirow{2}{*}{ Variance } & \multirow{2}{*}{$\begin{array}{c}\text { Highest } \\
\text { Variance }\end{array}$} & \multirow{2}{*}{$\begin{array}{c}\text { Lowest } \\
\text { Variance }\end{array}$} & \multirow{2}{*}{$F_{\text {observed }}$} & \multicolumn{2}{|c|}{$\mathbf{F}_{\text {table }}$} & \multirow{2}{*}{ Result } \\
\hline & & & & $\alpha(0.05)$ & $\alpha(0,01)$ & \\
\hline$A_{1}$ and $A_{2}$ & 43,82 & 26,32 & 1,67 & 4,17 & 7,56 & Homogeneous \\
\hline$B_{1}$ and $B_{2}$ & 70,33 & 49,20 & 1,43 & 4,17 & 7,56 & Homogeneous \\
\hline
\end{tabular}

The research data were normally distributed (see Table 2). Then, the next test is the homogeneity test. Homogeneity test data turned out to be homogeneous (see table 3), so the data analysis used was the parametric statistic of the twoway ANOVA test.

Table 4. Students' Emotional Intelligence Results Based on Personality Types and Learning Strategies

\begin{tabular}{|c|c|c|c|c|c|c|c|c|c|}
\hline $\begin{array}{l}\text { Emotional } \\
\text { Intelligence }\end{array}$ & $\begin{array}{c}\text { Max } \\
\text { Score }\end{array}$ & $\begin{array}{l}\text { Min } \\
\text { Score }\end{array}$ & Average & Mode & Median & Variance & $\begin{array}{l}\text { Standard } \\
\text { Deviation }\end{array}$ & Absolute & $\begin{array}{c}\text { Relative } \\
\text { Frequency }\end{array}$ \\
\hline Expository(A1) & 88 & 67 & 78,06 & 75 & 77 & 49,19 & 7,01 & 7 & 23 \\
\hline Inquiry $\left(\mathbf{A}_{2}\right)$ & 92 & 68 & 80,94 & 82 & 81 & 70,32 & 8,38 & 7 & 23,33 \\
\hline Extroverts $\left(B_{1}\right)$ & 88 & 67 & 81,17 & 78 & 82 & 85,63 & 9,25 & 9 & 30 \\
\hline Introverts $\left(\mathrm{B}_{2}\right)$ & 87 & 68 & 77,83 & 77 & 77 & 31,83 & 5,64 & 12 & 40 \\
\hline $\mathbf{B}_{1} \mathbf{A}_{1}$ & 88 & 67 & 76,78 & 69 & 77 & 65,12 & 8,07 & 6 & 40 \\
\hline $\mathbf{B}_{1} \mathbf{A}_{2}$ & 92 & 72 & 85,56 & 87 & 87 & 52,81 & 7,27 & 6 & 40 \\
\hline $\mathbf{B}_{2} \mathbf{A}_{1}$ & 87 & 73 & 79,33 & 73 & 77 & 31,74 & 5,63 & 6 & 40 \\
\hline $\mathbf{B}_{2} \mathbf{A}_{2}$ & 82 & 68 & 76,33 & 75 & 76 & 27,26 & 5,22 & 6 & 40 \\
\hline
\end{tabular}

The average values of emotional intelligence are varied (see table 4). The results obtained are supported by the results of the analysis of variance shown in table 5.

Table 5. Results of Analysis of Variance Data on Emotional Intelligence Scores

\begin{tabular}{|c|c|c|c|c|c|c|}
\hline \multirow{2}{*}{ Variance } & \multirow{2}{*}{$\begin{array}{l}\text { Degree of } \\
\text { Freedom }\end{array}$} & \multirow{2}{*}{$\begin{array}{c}\text { Number } \\
\text { of squares }\end{array}$} & \multirow{2}{*}{$\begin{array}{c}\text { RJK } \\
\text { (JK / dk) }\end{array}$} & \multirow[b]{2}{*}{ Fobserved $_{\text {ob }}$} & \multicolumn{2}{|c|}{$\mathbf{F}_{\text {critical }}$} \\
\hline & & & & & $\alpha(0.05)$ & $\alpha(0,01)$ \\
\hline Between A & 1 & 240 & 240 & 5.43 & & \\
\hline Between B & 1 & 180,27 & 180,27 & 4.07 & 4.01 & 7.11 \\
\hline Interactions of A X B & 1 & 749.07 & 749.07 & 16.93 & & \\
\hline In Groups & 56 & 2477,07 & 44,23 & - & - & - \\
\hline Total & 59 & 3646.4 & - & - & - & - \\
\hline
\end{tabular}

\section{Discussion and Conclusion}

The students' average emotional intelligence consists of different variations (see table 4). Emotional intelligence through the application of inquiry strategy is higher than emotional intelligence through the application of expository strategy $\left(X_{\mathrm{A} 2}=80.94>X_{A 1}=78.06\right)$. Besides, it is found that there are significant differences between the emotional intelligence of students subjected to the inquiry strategy and the expository strategy (see table 5). This is indicated by the value of $F_{0}=5,426>F_{0,05}(1 ; 56)=4.01$ which states that there is a difference between students' emotional intelligence who is subjected to inquiry learning strategy and students' emotional intelligence who is subjected to expository strategy. This happens because, in its application, the steps of the expository and inquiry strategy are different. So students have different tendencies in controlling emotional intelligence. Expository learning strategies prioritize the explanation of teachers through everyday life events while the inquiry strategy emphasizes the discovery of student orientation to everyday problems.

Indonesia is implementing curriculum 2013 by emphasizing problem orientation through daily life, thus, the inquiry strategy is very appropriate for implementing the curriculum in Indonesia today (Hidayati \& Prihatin, 2016; Kemendikbud, 2018; Sagala et al., 2019; Wekke \& Astuti, 2017). The results of this study are in line with the findings by (Felix et al., 2019), that the independence of students who are trained when learning takes place can guide them to find solutions to problems that occur in daily life and can better control their emotional intelligence.

Several other researchers have found that emotional intelligence affects employee performance. The better a person's performance, the better their emotional intelligence (Harahap \& Sagala, 2019; Mamangkey et al., 2018; Mulyasari, 2018; Nugraha, 2019), other studies have found other things that can affect emotional intelligence including social interaction (Damayanti, Putri, \& Wardani, 2014; Sahputra \& Hayati, 2019), coping strategies can also affect the emotional intelligence of working students (Felix et al., 2019), work that puts excessive pressure also affects emotional 
intelligence (Farrastama \& Asmony, 2019), expressing thoughts through writing can affect emotional intelligence (Kirk et al., 2011), and leadership can affect emotional intelligence (Allameh \& Khazaei, 2015; Krisnanda et al., 2019; Suryana, 2019). The previous studies on emotional intelligence are mostly applied in the work field, but in this study, it is applied in education. It can be concluded that the application of inquiry strategies that are oriented to problems in daily life support students to improve their emotional intelligence.

The emotional intelligence of students with extrovert personality is better than the emotional intelligence of students with introvert personality (see table 4). This is supported by a significant difference between the emotional intelligence of students who tend to extrovert personality types and students who have introvert personality type tendencies (see table 5). The emotional intelligence of students who tend to extrovert personality types is higher than students who tend introvert personality types $\left(\mathrm{X}_{\mathrm{BI}}=81.17>\mathrm{X}_{\mathrm{B} 2}=77.83\right)$. This reinforces the data that extrovert personality types play an important role in self-adjustment, especially those related to interpersonal dimensions whereas introvert personality types are shy, talk less, and tend to be self-centered (Parker \& Asher, 1993; Weinberger, 1990). The extrovert personality types are easier to socialize and can control their emotional intelligence.

The findings in Table 4 show that students with extrovert personality, through the application of inquiry strategy, are better than students with extrovert personality since the application of inquiry strategy are directed to find solutions from problem orientation in daily life (Abdurrahman, 2017; Choerunnisa et al., 2017; Dewi et al., 2017; Nasution, 2018). Students who have an extrovert personality type can easily explore a finding that can trigger curiosity. So that the inquiry strategy is easy and challenging to do for students who have an extrovert personality type tendency. The inquiry learning conducted requires students in groups to analyze the problems of the natural environment and the artificial environment in the surrounding environment.

The teacher posed problems in the natural and artificial environment in the surrounding environment. Then each group made questions and answers hypotheses from problems. Then, each group collected information to test the hypotheses made. The hypothesis was analyzed using several references and the students were given the freedom to explore by observing the natural and artificial environment that exists around the school. Then, each group concludes the findings on the learning that has been done. Besides, learning by doing group work makes it easy for extrovert personality types to socialize.

Table 4 also shows the emotional intelligence of students who have introvert personalities through the application of expository strategy is better than students who have introvert personality through the application of inquiry strategies. The expository learning strategy is teacher-centered. The teacher explained verbally assisted by displaying posters about the natural and artificial environment that exists in Indonesia. Students listened and understood the material delivered by teachers. Introvert personality type tended to learn on their own rather than collaborating, thus, providing learning with individual work methods making introvert students comfortable and easy to understand (Howorth et al., 2016; Mills et al., 2019; Roehling et al., 2017; Sugiharta, 2019; Syarofah, Wiryokusumo, \& Sugito, 2019). In expository learning, the teacher explained the objectives and material to be discussed in learning. Then, the teacher displayed posters about the natural and artificial environment that exists in Indonesia. Each student was directed to connect the material presented with daily life through the guidance of the teacher. Each student summarized the learning outcomes. The learning that has been applied is expected to make the students better understand the forms of the natural environment and artificial environment that exist in Indonesia and can preserve the natural and artificial environment in the surrounding environment by not littering.

Findings related to the interaction between learning strategies and tendencies of personality types are shown through the value of $F_{0}=16.93>F 0.05(1 ; 56)=4.01$ which states that there is an influence of learning strategies on emotional intelligence based on the tendency of personality types. Students who have an extrovert tendency are easy to socialize, have high self-confidence, and leadership so that they are very easy to control their emotional intelligence in terms of crowded and quiet situations. However, students who have an introvert tendency are very difficult to socialize, have low trust in a crowded situation so that they find it difficult to control their emotional intelligence when the situation is crowded and easier to control emotional intelligence in a quiet situation.

The findings of this study are that each student has different abilities and has different ways of learning. This research found that each personality type has a way to control emotional intelligence. Extrovert personality types and introvert personality types have different tendencies in controlling their emotional intelligence. Extrovert personality types tend to easily control their emotional intelligence by applying an inquiry learning strategy while introvert personality types are easier to control their emotional intelligence by applying an expository learning strategy.

Personality types and the application of strategies in learning affect students' emotional intelligence. Students who tend to extrovert personality types are better at controlling their emotional intelligence than students who have an introvert personality type. The application of inquiry strategy in learning is better at controlling emotional intelligence than the application of expository strategy. Also, students who tend extrovert personality type, to better control their emotional intelligence, should be given an inquiry learning strategy whereas students who have introvert personality type tendencies better control their emotional intelligence by applying expository learning strategy. 


\section{Recommendation}

In this study, it is clear that personality types and the application of strategies in learning affect students' emotional intelligence. Therefore, teachers must pay attention to this to develop the skills that each student has. The skills can be affective, psychomotor, and cognitive.

\section{References}

Abdurrahman. (2017). Efektivitas dan kendala pembelajaran sains berbasis inkuiri terhadap capaian dimensi kognitif siswa : Meta analisis [The effectiveness and the problem of inquiry-based science learning on students' cognitive achievement: Meta analysis]. Tadris: Journal of Education and Teacher Training/Tadris: Jurnal Keguruan Dan Ilmu Tarbiyah, 2(1), 1-9. https://doi.org/https://doi.org/10.24042/tadris.v2i1.1206

Allameh, S. M., \& Khazaei, J. P. (2015). The impact of emotional intelligence on transformational leadership and leader effectiveness. Latin American J. Management for Sustainable, 2(1), 83-93.

Argyriou, E., Bakoyannis, G., \& Tantaros, S. (2016). Personality and social psychology parenting styles and trait emotional intelligence in adolescence. Scandinavian Journal of Psychology, 57, 42-49. https://doi.org/10.1111/sjop.12266

Asmawati, L. (2017). Peningkatan kreativitas anak usia dini melalui pembelajaran terpadu berbasis kecerdasan jamak [The improvement of creativity of early childhood through multiple intelligence based-integrated learning]. Journal of Early Education/Jurnal Pendidikan Usia Dini, 11(1), 145-164. https://doi.org/https://doi.org/10.21009/JPUD.111.10

Asmuniv. (2015). Pendekatan terpadu pendidikan STEM upaya mempersiapkan sumber daya manusia Indonesia yang memiliki pengetahuan interdisipliner dalam menyosong kebutuhan bidang karir pekerjaan Masyarakat Ekonomi ASEAN (MEA) [STEM learning integrated approach efforts to prepare Indonesian human resources who have interdisciplinary knowledge in supplying needs in the field of career of the ASEAN Economic Community (AEC)]. Retrieved from http://www.vedcmalang.com/pppptkboemlg/index.php/menuutama/listrik-electro/1507-asv9

Athariq, M. I., \& Andayono, T. (2019). Pengaruh kecerdasan emosional terhadap hasil praktek kerja industri siswa kelas XII Smk Negeri 1 Lintau Buo [The effect of emotional intelligence on industrial work practices results of class XII students of SMK Negeri 1 Lintau Buo ]. Cived: Journal of Civil Engineering and Vocational Education, 6(2), 23023341.

Baharuddin, \& Dalle, J. (2019). Transforming learning spaces for elementary school children with special needs. Journal of Social Studies Education Research, 10(2), 344-365.

Baidi. (2019). The role of parents' interests and attitudes in motivating them to homeschool their children. Journal of Social Studies Education Research, 10(1), 156-177.

Birks, Y., Mckendree, J., \& Watt, I. (2009). Emotional intelligence and perceived stress in healthcare students : a multiinstitutional, multi-professional survey. BMC Medical Education, 9(6), 1-8. https://doi.org/10.1186/1472-6920-961

Brunetto, Y., Teo, S. T. T., Shacklock, K., \& Farr-Wharton, R. (2012). Emotional intelligence, job satisfaction, well-being and engagement: explaining organizational commitment and turnover intentions in policing. Human Resource Management Journal, 22(4), 428-441. https://doi.org/10.1111/j.1748-8583.2012.00198.x

Cartwright, S., \& Pappas, C. (2008). Emotional intelligence, its measurement and implications for the workplace. International Journal of Management Reviews, 10(2), 149-171. https://doi.org/10.1111/j.14682370.2007.00220.x

Choerunnisa, R., Wardani, S., \& Sumarti, S. S. (2017). Keefektifan pendekatan contextual teaching learning dengan model pembelajaran inkuiri terhadap literasi sains [Effectiveness of contextual teaching learning approach with inquiry learning model on scientific literacy ]. Journal of Chemical EducationInnovaton/Jurnal Inovasi Pendidikan Kimia, 11(2), 1945-1956.

Damayanti, O. P., Putri, M. A., \& Wardani, H. (2014). Pengaruh konformitas teman sebaya dan kecerdasan emosional terhadap sikap seks pranikah pada remaja [Effects of peer conformity and emotional intelligence on premarital sex attitudes in teenagers]. Mind Set, 6(1), 27-34.

Dewi, E. P., Suyatna, A., \& Ertikanto, C. (2017). Efektivitas modul dengan model inkuiri untuk menumbuhkan keterampilan proses sains siswa pada materi kalor [Effectiveness of modul with inquri model to grow students' science process skills on heat material]. Tadris: Journal of Education and Teacher Training/ Tadris: Jurnal Keguruan Dan Ilmu Tarbiyah, 2(2), 105-110.

Dewi, P. S. (2016). Perspektif Guru Sebagai Implementasi pembelajaran inkuiri terbuka dan inkuiri terbimbing 
terhadap sikap ilmiah dalam pembelajaran sains [Teacher's perspective as implementation of open inquiry learning and guided inquiry on scientific attitude in science learning]. Tadris: Journal of Education and Teacher Training/Tadris: Jurnal Keguruan Dan Ilmu Tarbiyah, 1(2), 179-186.

Farrastama, D. N., \& Asmony, T. (2019). Effect of emotional intelligence on counterproductive work behavior with job stress as an intervening variable: Study on civil servants in Mataram city. International Journal of Social Science and Humanities, 3(1), 14-25.

Felix, T., Marpaung, W., Akmal, M. El. (2019). Peranan Kecerdasan Emosional Pada Pemilihan Strategi Coping Pada Mahasiswa yang Bekerja [The Role of Emotional Intelligence in the Selection of Coping Strategies in Working Students]. Persona: Jurnal Psikologi Indonesia, 8(1), 39-56.

Ferreira, B., Morais, D. B., Brothers, G. L., \& Ferreira, B. (2019). Enhancing self-efficacy to enable tourism microentrepreneurship: A quasi-experiment. Journal of Teaching in Travel \& Tourism, 1-19. https://doi.org/10.1080/15313220.2019.1598920

Feyerhem, A. E., \& Rice, C. L. (2002). Emotional intelligence and team performance-the good the bad and the ugly. The International Journal of Organizational Analysis, 10(4), 343-362.

Fitriani, W., Irwandi, D., \& Murniati, D. (2017). Perbandingan model pembelajaran Process Oriented Guided Inquiry Learning (POGIL) dan Guided Inquiry (GI) terhadap keterampilan berpikir kritis [Comparison of Process Oriented Guided Inquiry Learning (POGIL) and Guided Inquiry (GI) learning model for critical thinking skills]. Journal of Chemical Education Research/Jurnal Riset Pendidikan Kimia, 7(1), 76-84.

Goleman, D. (2001). Emotional intelligence (Issues in Paradigm Building). San Fransisco, CA: Jossey-Bass.

Hanana, N. F. (2018). Pengaruh self-esteem dan kecerdasan emosi terhadap perilaku prososial [Effect of self-esteem and emotional intelligence on prosocial behavior]. Tazkiya Journal of Psychology, 6(1), 85-100.

Harahap, D. A. F., \& Sagala, E. J. (2019). Pengaruh kecerdasan emosional terhadap kesiapan kerja pada mahasiswa paramedic [Effect of emotional intelligence on paramedic student]. Accountabel/Akuntabel, 16(1), 47-53.

Haryadi, T. (2015). Sekolah dasar melalui perancangan game simulasi [Elementary school through game simulation design]. Journal of Visual and Multimedia Communication Design/Jurnal Desain Komunikasi Visual \& Multimedia, $1(2), 39-50$.

Hedges, H., \& Lee, D. (2010). I understood the complexity within diversity': preparation for partnership with families in early childhood settings. Asia-Pacific Journal of Teacher Education, 38(4), 257-272.

Hidayati, D. (2016). Memudarnya nilai kearifan lokal masyarakat dalam pengelolaan sumber daya air [Waning community local wisdom values in water resources management]. Journal of Indonesian Population/Jurnal Kependudukan Indonesia, 11(1), 39-48.

Hidayati, I. F., \& Prihatin, T. (2016). Pengelolaan kurikulum sekolah alam di TK Alam Al Biruni Cirebon [Management of nature school curriculum at Alam Al Biruni Kindergarten Cirebon]. Indonesian Journal of Curriculum and Educational Technology Studies, 4(1), 32-39.

Howorth, S., Lopata, C., Thomeer, M., \& Rodgers, J. (2016). Effects of the TWA strategy on expository reading comprehension of students with autism. British Journal of Special Education, 43(1), 39-59. https://doi.org/10.1111/1467-8578.12122

Ibrahim. (2012). Pengaruh kecerdasan emosional terhadap organizational citizenship behavior dan dampaknya pada kinerja perawat Rumah Sakit Umum Anutapura dan Rumah Sakit Undata Palu [Effect of emotional intelligence on organizational citizenship behavior and it's impact on the performance of nurses at Anutapura General Hospital and Undata Hospital in Palu]. Cataloger/Katalogis, 1(1), 136-146.

Indrawati, R. M. (2013). Peningkatan aktivitas dan hasil belajar materi peristiwa sekitar proklamasi melalui bermain peran [Improving activites and learning outcomes on the events around the proclamation subject through role play]. Journal of Elementary Education, 2(4), 15-22.

Indriawati, P. (2018). Pengaruh Kepercayaan diri dan kecerdasan emosional terhadap hasil belajar mahasiswa Universitas Balikpapan [The effect of confidence and emotional intelligence on student learning outcomes at Universitas Balikpapan]. Journal of Edutama Education/Jurnal Pendidikan Edutama, 5(2), 1-9.

Irmawati, F., Oktaviana, I., \& Rahayu, L. (2016). Pengembangan bahan ajar pengetahuan lingkungan berbasis web untuk meningkatkan motivasi mahasiswa IKIP Budi Utomo Malang [Development of web-based environmental science teaching material to increase students' motivation in IKIP Budi Utomo Malang]. Florea Journal/Jurnal Florea, 3(1), $12-20$.

Keeler, L. A., Skidmore, B., Leenstra, T., Macdonald, J. R., \& Stewart, D. (2019). Treating university students' depression 
using physical activity with peers : Two field-based quasi-experiments grounded in the self- determination theory. Journal of College Student Psychotherapy, 1-19. https://doi.org/10.1080/87568225.2019.1660293

Kemendikbud. (2018). Permendikbud No. 21 Tahun 2016 tentang Standar Isi Kurikulum 2013 [Minesterial of Education and Culture Regulation number 21 of 2016 about Curriculum Standards of 2013]. Jakarta.

Kidwell, B., Hardesty, D. M., \& Childers, T. L. (2008). Association for consumer research. Advances in Consumer Research, $35,660-662$.

Kirk, B. A., Schutte, N. S., \& Hine, D. W. (2011). The effect of an expressive-writing intervention for employees on emotional self-efficacy, emotional intelligence, affect, and workplace incivility. Journal of Applied Social Psychology, 41(1), 179-195.

Komarudin, Alkhudri, A. T., Ubedilah, Syaifudin, \& Casmana, A. R. (2019). The nationality education model: The implementation of a score-a training model for youth across different cultures in Indonesia. Journal of Social Studies Education Research, 10(2), 308-322.

Krisnanda, P. H., Bagus, I., \& Surya, K. (2019). Effect of emotional and spiritual intelligence on transformational leadership and impact on employee performance. International Research Journal of Management, IT \& Social Sciences, 6(3), 70-82.

Luan, J. J. S. A., \& Blegur, J. (2018). Potret kecerdasan emosional mahasiswa pada perkuliahan seminar pendidikan jasmani [Portrait of student emotional intelligence at physical education seminar lectures]. Sebatik, 23(1), 195202.

Mamangkey, L. A. G., Tewal, B., \& Trang, I. (2018). Pengaruh Kecerdasan Intelektual (IQ), Kecerdasan Emosional (EQ), dan Kecerdasan Sosial (SQ) terhadap kinerja karyawan kantor wilayah bank BRI Manado [The effect of Intelligence Quotient(IQ), Emotional Quotient (EQ), and Social Quotient (SQ) on employee performance of bank BRI regional office Manado]. Journal of EMBA/Jurnal EMBA, 6(4), 3208-3217.

Mills, C., Wu, J., \& Mello, S. D. (2019). Being sad is not always bad: The influence of affect on expository text comprehension. Discourse Processes, 56(2), 99-116. https://doi.org/10.1080/0163853X.2017.1381059

Mujib, \& Mardiyah. (2017). Kemampuan berfikir kritis matematis berdasarkan multiple intelligences [Mathematical critical thinking abilities based on multiple intelligences]. Al-Jabar: Journal of Mathematic Education/Al-Jabar: Jurnal Pendidikan Matematika, 8(2), 188.

Mulyasari, I. (2018). Pengaruh kecerdasan emosional dan kompetensi terhadap kinerja pegawai [The effect of emotional intelligence and competence on employee performance]. Journal of Management Review, 2(2), 190-197.

Nasution, S. W. R. (2018). Penerapan model inkuiri terbimbing (guided inquiry) dalam meningkatkan kemampuan berpikir kritis pada pembelajaran fisika [Application of Guided inquiry model in improving the critical thinking ability in physics learning]. Journal Education and Development, 3(1), 1-5.

Nugraha, S. (2019). Kecerdasan emosional dan perilaku kewarganegaraan organisasi pada pegawai badan kepegawaian daerah [Emotional intelligence and organizational citizenship behavior for regional civil service agency employees]. Business Innovation and Entrepreneurship Journal, 1(1), 62-67. Retrieved from https://doi.org/10.35899/biej.v1i1.3

O'Boyle Jr, E. H., Humphrey, R. H., Pollack, J. M., Hawver, T. H., \& Story, P. A. (2011). The relation between emotional intelligence and job performance: A meta-analysis. Journal of Organizational Behavior, 32(5), 788-818. https://doi.org/10.1002/job.714

Parker, J. G., \& Asher, S. R. (1993). Friendship and friendship quality in middle childhood: link with peer group acceptance and feelings of loneliness and social dissatisfaction. Journal of Developmental Psychology, 29(4), 611621.

Parmar, P., Harkness, S., \& Super, C. (2004). Asian and Euro-American parents' ethnotheories of play and learning: effects on children's home routines and school behavior. International Journal of Behavioral Development, 28(2), 97-104.

Parmin, P., Nuangchalerm, P., \& El, R. A. Z. (2019). Exploring the indigenous knowledge of java north coast community (Pantura) using the Science Integrated Learning (SIL) model for science content development. Journal for the Education of Gifted Young, 7(1), 71-83. https://doi.org/10.17478/jegys.466460

Purnamawati, D., Ertikanto, C., \& Suyatna, A. (2017). Keefektifan Lembar kerja siswa berbasis inkuiri untuk menumbuhkan keterampilan berpikir tingkat tinggi [The effectiveness of inquiry-based student worksheets to grow higher-order thinking skills]. Scientific Journal of Physical Education Al-Biruni/Jurnal Ilmiah Pendidikan Fisika Al-BiRuNi, 6(2), 209-219. https://doi.org/10.24042/Jipfalbiruni.V6i2.2070 
Rachmawati, Y., \& Kurniati, E. (2011). Strategi pengembangan kreativitas pada anak usia dini taman kanak-kanak [Creativity development strategies in early childhood kindergartens]. Jakarta, Indonesia: Kencana Pranada Media Grup.

Rasyid, M., Apriani, I. D., Irianti, S., \& Verlanda, A. (2017). “Dice of Feelings” Untuk Meningkatkan Self-disclosure Pada Remaja Tipe Kepribadian Introvert ["Dice of feelings" to increase self-disclosure in teenagers introverted personality types]. Psikostudia: Journal of Psychology/Psikostudia: Jurnal Psikologi Vol, 6(1), 17-24.

Respati, W. S., Arifin, W. P., \& Ernawati. (2007). Gambaran kecerdasan emosional siswa berbakat di kelas akselerasi SMA di Jakarta [Description of emotional intelligence of talented students in high school acceleration classes in Jakarta]. Jurnal Psikologi, 5(1), 30-61.

Rita. (2019). The effect of learning methods and learning motivation on Indonesian learning outcomes class X students of Panca Budi Medan High School. BirLE-Journal, 2(1), 132-137.

Roehling, J. V, Hebert, M., Nelson, J. R., \& Bohaty, J. J. (2017). Text structure strategies for improving expository reading comprehension. International Literacy Association, 71(1), 71-82. https://doi.org/10.1002/trtr.1590

Sagala, R., Nuangchalerm, P., Saregar, A., \& El Islami, R. A. Z. (2019). Environment-friendly education as a solution to against global warming: A case study at Sekolah Alam Lampung, Indonesia. Journal for the Education of Gifted Young Scientists, 7(2), 85-97.

Sahputra, D., \& Hayati, R. (2019). Kontribusi Kepercayaan Diri dan Kecerdasan Emosi Terhadap Interaksi Sosial [Contribution of Confidence and Emotional Intelligence towards Social Interaction]. In Proceedings of the National Conference and Expo on the Results of Research and Public Devotion/Prosiding Seminar Nasional \& Expo Hasil Penelitian dan Pengabdian Masyarakat (pp. 560-568).

Saregar, A., Giyoti, G., Ariyani, F., Pawe TI., Pricilia, A., \& Astriawan, D. (2019). How to Design Physics Posters Learning Media with Islamic Values in Developing Learning Motivation and Student Character?. Journal of Physics: Conference Series, 1155(1), 1-9.

Sakib, N., Muhammad, S., \& Osman, I. (2019). Syrian refugee influx and the rise of far-right rhetoric: a quasiexperimental investigation. European Politics and Society, 20(4), 1-13. https://doi.org/10.1080/23745118.2019.1634352

Sinetar, M. (2000). Spiritual intelligence, kecerdasan spiritual: Belajar dari anak yang mempunyai kesadaran dini [Spiritual intelligence: Learning from children with early consciousness]. (S. Budidarmo, Trans. Ed.). Jakarta, Indenosia: Elex Media Komputindo.

Soemarmi, K. (2017). Upaya meningkatkan kemampuan berbicara bahasa jepang melalui metode bermain peran (role play) [Improving speaking japanese ability through the role play method]. BRILLIANT: Journal of Research and Conceptual/BRILLIANT: Jurnal Riset dan Konseptual, 2(2), 225-230. Retrieved from http://www.jurnal.unublitar.ac.id/

Sudrajat, A., Iasha, V., \& Femayati, F. (2018). The influence of the use of cooperative learning model jigsaw \& two stay two stray and the learning interest result on 5 th grade social science. Proceeding Book of 1st International Conference on Educational Assessment and Policy, 2, 28-33.

Sugiharta, S. (2019). Upaya Meningkatkan Prestasi Belajar Biologi dengan Strategi Pembelajaran Ekspositori [Improving Biology Learning Achievement with Expository Learning Strategies]. Journal of Learning Innovation/Jurnal Inovasi Pembelajaran, 5(2), 1-6.

Suryana. (2019). Pentingnya kecerdasan emosi bagi kepemimpinan yang efektif di era milenial revolusi 4.0. [The importance of emotional intelligence for effective leadership in the millennial era of the revolution 4.0.]. Journal of Inspairing/Jurnal Inspirasi, 10(1), 78-97.

Syarofah, F., Wiryokusumo, I., \& Sugito. (2019). Penerapan metode discovery learning dan ekspositori terhadap peningkatan hasil belajar PKN siswa kelas 7 SMP Negeri 2 dan SMP Negeri 7 Bangkalan [Application of discovery learning and expository methods to the improvement of civics learning outcomes of class 7 students of SMP Negeri 2 and SMP Negeri 7 Bangkalan]. Journal Education and Development, 7(2), 222-226.

Valoka, M., Tsausi, I., \& Nikolaou, I. (2004). The Role of Emotional Intelligence and personality variables on attitudes Toward Organisational Change. Journal of Managerial Psychology, 19(2).

Wangsa-P., P. G., Suyana, I., Amalia, L., \& Setiawan, A. (2017). Upaya meningkatkan kemampuan komunikasi dan pemahaman konsep siswa melalui pembelajaran inkuiri berbantu teknik TSTS [Improving communication skills and student concepts understanding through inquiry learning assisted with TSTS]. Journal of Physical Education Forum/Jurnal Wahana Pendidikan Fisika, 2(2), 27-31. 
Warjiyono. (2016). Penerapan green computing dalam upaya efesiensi sumber daya di Amik BSI Tegal [Implementation of green computing in the efforts of resource efficiency at Amik BSI Tegal]. IJSE - Indonesian Journal on Software Engineering, 2(1), 52-56.

Weinberger, J. (1990). The family origins of emphatic concern: A-26 year longitudinal study. Journal of Personality and Social Psychology, 38(4), 709-717.

Wekke, I. S., \& Astuti, R. W. (2017). Kurikulum 2013 di Madrasah Ibtidaiyah : Implementasi di wilayah minoritas Muslim [2013 Curriculum in Madrasah Ibtidaiyah: Implementation in Muslim minority areas]. Tadris: Jurnal Keguruan Dan Ilmu Tarbiyah, 2(1), 33-39. https://doi.org/10.24042/tadris.v2i1.1736

Widayanti, Abdurrahman, \& Suyatna, A. (2019). Future Physics learning materials based on STEM education : Analysis of teachers and students perceptions. Journal of Physics Conferences Series, 1155, 1-9. https://doi.org/10.1088/1742-6596/1155/1/012021

Yang, K., Wang, T., \& Chiu, M.-H. (2015). Study the effectiveness of technology-enhanced interactive teaching environment on student learning of junior high school Biology. Eurasia Journal of Mathematics, Science \& Technology Education, 11(2), 263-275.

Yuberti, Latifah, S., Anugrah, A., Saregar, A., Misbah, \& Jermsittiparsert, K. (2019). Approaching problem-solving skills of momentum and impulse phenomena using context and problem-based learning. European Journal of Educational Research, 8(4), 1217-1227. https://doi.org/10.12973/eu-jer.8.4.1217

Zaini, A. (2015). Bermain sebagai metode pembelajaran bagi anak usia dini [Playing as a Learning Method for Early Childhood]. ThufuLA: Journal of Early Childhood Teacher Education/ThufuLA: Jurnal Inovasi Pendidikan Guru Raudhatul Athfal, 3(1), 118-134. 